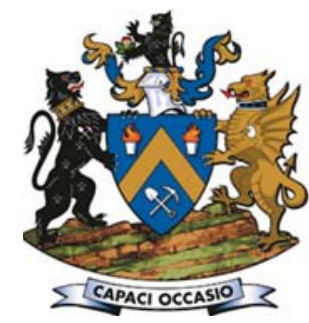

\title{
Monitoring ore loss and dilution for mine-to-mill integration in deep gold mines: a survey-based investigation
}

\author{
by L. Xingwana*
}

\section{Synopsis}

The purpose of this study is to understand how ore loss and dilution affect the mine call factor, with the aim of subsequently improving the quality of ore mined and fed to the mill. It was necessary to know the relationship between ore mined and delivered for processing in order for the mine to operate efficiently. A review of the literature suggested the mine-to-mill integration approach as a standard intervention to address declining mine call factors. A case study was undertaken at a gold mine in the Free State on the influence of the fragment size distribution on 'free gold', the effect of ore loss and dilution on the mill efficiency, and time tracking of ore movement from source to the plant. The study revealed that fragmentation, underground accumulation of ore, and dilution have a significant influence on the mine call factor and mine output. It was difficult to quantify the total ore loss due to the time lag between mining and milling, which is extremely variable, when estimating the mine process inventory. However, it was possible to estimate the total dilution with some degree of precision by analysing the daily blast and head grades. It is therefore recommended that mines accept that some gold loss and dilution will always occur during blasting and transport of broken ore, and this loss must be minimized.

Keywords

Mine call factor, mine-to-mill integration, fragmentation, ore loss, dilution.

\section{Introduction}

The mining of high gold grades is obviously very beneficial for the economic viability of an operation, but optimum recovery of the product is required to maximize profits (Chapman and Bindoff, 2010, p. 13). Although integrating these two requirements is very difficult, due to the various activities occurring between mining and processing, it is indispensable. The main driver of this integration is the impact that different ore types and characteristics have on head grade. According to Isokangas et al. (2012, p. 871), mining and processing operations involve a series of well-defined sequential stages that are complementary in an efficiently operating mine, with the performance of one operation affecting that of another. An attempt to optimize each function separately without considering the whole extraction process will not result in the optimum efficiency of the entire mine. Several researchers have developed a proven methodology for revealing these inefficiencies (Dance et al., 2006, p. 1).
In recent years, JKTech, W.H. Bryan Research Centre (BRC), and the Julius Kruttschnitt Mineral Research Centre (JKMRC) have introduced mine-to-mill integration as a holistic approach to process optimization that would maximize the overall profitability (Rogers et al., 2012). Most of these studies considered open pit mining (Ebrahimi, 2013, p. 2) and pit-to-plant operations (Gillot, 2004, p. 1) as subjects and then generalized these specific results to underground mining operations. In most cases, these results were not applicable to underground gold mining operations. Despite the interest in investigating mine-to-mill integration at individual gold mines (Bamber, 2008, p. 5; Grundstrom et al., 2001), information on ore loss and dilution is relatively scarce as few reliable works have been documented that are applicable to conditions in South African gold mines (Onederra, 2004, p. 1). Moreover, very few techniques were previously available to measure the size distribution of rock fragments in mining and processing operations (Kanchibotla, Valery, and Morrell, 1999, p. 137). It is now possible to simultaneously evaluate in-stope fragmentation, monitor ore loss and dilution, and track ore movement in deep-level gold mining.

For the mine to operate efficiently, it is necessary to compare the actual product recovered with the desired target. These two estimations must be as close to each other as possible; or equated to approximately 100 per cent, a situation that is impossible in practice. From a grade control perspective, the multitude of errors and inaccuracies with regard to the estimated gold content of the reef are hidden in the mine call factor (MCF) (Chieregati and

\footnotetext{
* Sibanye Gold, Welkom, South Africa.

(C) The Southern African Institute of Mining and Metallurgy, 2016. ISSN 2225-6253. This paper was first presented at the, Mining Business Optimization Conference 2015, 11-12 March 2015, Mintek, Randburg.
} 


\section{Monitoring ore loss and dilution for mine-to-mill integration in deep gold mines}

Pitard, 2009, p. 108; De Jager, 2005, p. 56). From the investor perspective, $40 \%$ of ore reserves are left behind as support pillars, and this percentage will increase as the depth of mining increases. Of the $60 \%$ remaining and that can be mined, $20 \%$ to $30 \%$ of the gold-bearing particles are lost in the chain of operations between the source and processing plant. This issue is further exacerbated by $50 \%$ to $100 \%$ dilution of the product, which adds to processing costs (Candy, 2014). Focusing on ore dilution to increase head grade is not a new subject. However, emphasis on generating more tonnage to the mill in mining operations has resulted in loss of focus in this area. There is a need to close this gap.

The primary objective of this study was to understand how ore loss and dilution affect the MCF and to subsequently improve the quality of ore mined and fed to the mill. On the basis of this objective, the basic research question is:

What is the impact of ore movement on the head grade in a deep-level gold mine?

In subsequent sections. the theoretical framework of the study is outlined and the research methodology described. Finally, the paper presents the empirical results of the investigation, the main conclusions, and recommendations.

\section{Theoretical model of mine-to-mill integration}

A study by Bamber $(2008$, p. 5) highlighted two approaches of mine-to-mill integration, namely operational and physical integration. Operational integration includes the use of drill and shovel monitoring technologies, optimization of the blast fragmentation and communition processes, and improved monitoring in the pit and ore handling system. On the other hand, physical integration includes fragment size classification, sorting, improving grade control, and improving mill feed grades. Optimization of the blast fragmentation and improving grade control and feed grades are the focal points of this study. Based on an analysis of the study by Bamber (op. cit.), it was possible to construct a model of mine-to-mill integration in deep-level gold mines. Figure 1 depicts the impact of the blast movement dynamics on the MCF in a theoretical model.

Figure 1 indicates the three components of mine-to-mill integration, namely fragmentation, ore loss, and dilution, which when addressed on an individual basis would not show a significant effect on the MCF but when considered jointly may affect output levels and profit margin significantly. The mine therefore needs to optimize blast

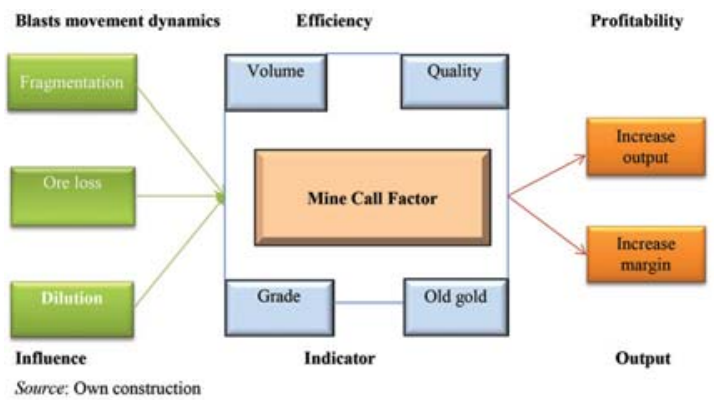

Figure 1-Theoretical model of mine-to-mill integration in a deep-level gold mine fragmentation and to deliver sufficient ore tonnage (volume and old gold) at the required mill grade (quality and grade) to the metallurgical plant.

\section{Clarification of concepts}

Mine-to-mill integration, MCF, fragmentation, ore loss, and dilution may have different connotations for people working in various mining disciplines, in particular those that are not working in mineral resource management (MRM) or at the mines. These concepts are clarified below.

\section{Mine}

Mining is a process of delving into the Earth to extract naturally occurring minerals, either on surface or underground, and quarrying for construction materials. For this study, mining includes the processes of drilling, blasting, and ore movement (handling, loading, and hauling) to the main shaft orepasses.

\section{Mill}

Milling is the process of crushing, grinding, and treating of raw material from the mine to extract a saleable product. It also involves the processes of hoisting and transporting of broken ore to the mill via trucks or conveyor belts.

\section{Mine-to-mill integration}

This is an approach to reconcile the blasted material at the stope face with the hoisted raw material at the shaft to provide accurate information about the quality of ore that is delivered to the plant. This approach allows the grade control officers to reduce the grade variability of the ore sent for processing and thus increase the predictability of the gold recovery. The predictability can be measured based on a comparison of the estimated and actual ore tonnage and grade. The outcome of this comparison is a factor such as the stope call factor $(\mathrm{SCF})$, shaft call factor, tramming factor, recovery factor, extraction factor, overall recovery factor, plant call factor, and MCF, to name but a few (Chieregati and Pitard, 2009, p. 107; Andersen, 1999, p. 4). The emphasis in this paper is on the MCF.

\section{Mine call factor}

The mine survey department is responsible for measuring and recording waste and ore broken underground, as indicated in ore flow calculations. All tonnages from different sources, including surface stockpiles, are added together, and compared with the actual tonnage received at the plant. The difference is known as tonnage discrepancy and is indicated by the MCF. The MCF is the ratio, expressed as percentage, of the specific product accounted for in the recovery, plus residues, and the corresponding product called for by the mine's measuring and evaluation methods. The objective of the MCF is two-fold. Firstly, it is used to investigate what happened to the ore tonnage and gold content that is not reflected further along the production stream. Secondly, it determines how much of the product was lost in the extraction system (Macfarlane, 2011, p. 429; De Jager, 2005, p. 55) or gives an indication of how accurate the estimate turned out to be compared to the quantity of metal recovered plus residue (Chieregati and Pitard, 2009, p. 107; Minnitt, 


\section{Monitoring ore loss and dilution for mine-to-mill integration in deep gold mines}

2007, p. 453). These comparisons must be as close as possible or equate to approximately $100 \%$, a situation that is impossible in practice, hence a MCF of $85 \%$ was considered reasonable.

\section{Fragmentation}

The main goal of blasting is to produce manageable rock fragments for ease of cleaning, handling, loading, and crushing in order to minimize total production costs per ton blasted (Zagreba, 2003, p. 3). Fragmentation may be defined as the size distribution of rock fragments (Cho and Kaneko, 2004 , p. 1722) and is dependent on the rock properties, specific drill spacing and charge pattern, explosives properties, and explosion gas pressure (Cho and Kaneko, 2004. p. 1722; La Rosa and Thornton, 2011, pp. 300-302; Thornton, Kanchibotla, and Brunton, 2002). Recent studies tend to support the view that certain explosive types produce better fragmentation than others, and the MCF can be improved through better fragmentation (Rajpot, 2009, p. 54).

\section{Ore loss}

The movement of ore in the stope is by blasting, face cleaning, gully scraping, and loading from the orepass. These processes result in some ore not reaching the intended destination. Ore loss refers to any unrecoverable economic ore left inside a stope (broken, in place as pillars, or not properly blasted at the boundaries), or to any valuable ore not recovered by the mineral processing system. The tonnage accumulations consist of current broken ore that is called for by mine measuring methods but was not removed in time to be incorporated in the current metal accounting system. When this broken ore is finally removed, probably by the vamping section, it is classified as 'old gold' and is then called for again (Andersen, 1999, p. 15). The failure to remove the ore can create bottlenecks (Rupprecht, 2003, p. 53 ) and causes a low MCF, ultimately complicating the mineto-mill reconciliation as broken does not reach the surface timeously, if at all. Ore losses also arise when valuable material is misclassified as waste and sent to the waste dumps (Engmann et al., 2013, p. 27).

\section{Ore dilution}

The broken material from a stope is a mixture of reef and waste rock. The proportion of waste to reef depends on many factors, including reef width, waste width, faults, intrusions, and mining practices. Dilution may occur as a result of lowgrade or waste material mixing with ore during the operation and being sent for processing, thus reducing the ore value (Chieregati and Pitard, 2009, p. 110) or any waste material within a mining block (Yilmaz, 2011, p. 94). Dilution can be quantified as the ratio of the tonnage of waste mined and sent to the mill to the total tonnage of ore plus waste that is milled (Wang et al., 2011, p. 334). It is always expressed as a percentage:

$$
\text { Dilution }=\frac{\text { Waste tons }}{\text { Ore plus waste tons }} \times 100
$$

\section{Methodology}

A case study was undertaken at a gold mine in South Africa's Free State Province of the influence of fragment size distribution on 'free gold', the effect of ore loss and dilution on the mill efficiency, and time tracking of ore movement from source to the plant. The sampling frame was restricted to all current underground working places, referred to in this study as stope panels. The study was correlational in nature as it was designed to establish the relationship between the actual measurements of the ore hoisted from underground and estimates of the ore blasted at the stope face underground in order to improve the MCF. Specifically, the aim was to predict quantitatively the effect of ore handling and transport on the ore grade sent to the plant and determine the statistical significance of the estimated relationships. This would be possible with the application of the mine-to-mill approach considering in-stope fragmentation, dilution, ore loss, and tracking in the form of four exercises.

The first exercise examined the size distribution of rock fragments to minimize and control loading, hauling, and crushing costs, using digital photography and direct observation. Twenty images of broken ore in stopes 4 and 6 were used to measure the size distribution of blasted fragments. According to Siddiqui, Ali Shah, and Behan (2009, p. 83), image acquisition is crucial in the analysis of fragment size distribution. The images were taken randomly and systematically, at an angle that ensured the surfaces of fragments were photographed in full, while balls of $20 \mathrm{~mm}$ in diameter and tennis balls were used to provide the scale of the images at the stope face, gully, boxhole vicinity, and crosscut. These images were then downloaded into the SPLIT Desktop program for analysis. According to Siddiqui, et al. (2009, p. 83), there are several software packages, such as SPLIT, GoldSize, FragScan, PowerSieve, etc. that are commercially available to quantify size distribution. The rationale behind choosing SPLIT Desktop for size distribution was that the accuracy of these systems is presumed to be between $2 \%$ and $20 \%$. To check the reliability of visual observations of the muck pile underground, online digital cameras were mounted at a strategic point on surface. These cameras automatically captured images of ore on a moving conveyor belt, analysed the size distribution of the rocks with the SPLIT image analysis system, and reported the rock size statistics and passing percentage.

The second exercise was the gap analysis that would help the business understand and quantify the grade gap that exists between the estimate of mine production and actual grade entering the plant. The data was collected through observation and grab sampling methods. Grab samples were collected at the top, middle, and bottom of the stope face and at the cross-section of various points (strike and dip gullies) and the mean value of these points was used for the analysis. The representativeness of these samples was considered fair insofar that they represented high-, medium-, and low-grade panels and were sufficient to indicate the grade gap along the ore stream. For this study, a SCF score of $60 \%$ or more was considered to be practically significant and to confirm convergent validity. Grab sampling was used as a method of reconciling the daily blasted grade to the predicted daily head grade (Dominy, 2010, p. 277) and not for metal accounting purposes (Spangenberg, 2012, p. 73). Numbered samples weighing about $500 \mathrm{~g}$ each were collected from muck piles of broken ore at the stope face, gully cross-sections, boxhole, 


\section{Monitoring ore loss and dilution for mine-to-mill integration in deep gold mines}

and crosscut. The samples were securely packed, transported to the assay laboratory, and assayed to determine gold and silver values. This method of grab sampling was used with extreme caution to avoid over-sampling of fines, pick-up, and preferential selection of high-grade fragments. For instance, a large sample was drawn, reduced to the required size of $500 \mathrm{~g}$ by quartering, and then sent to the assay laboratory. In this way, more representative samples were obtained.

The third exercise was the process system analysis using a material census checklist as the measuring instrument. The rationale behind this step was to pinpoint flaws in the grade control methods and examine whether the grade control system was properly established, operated at maximum efficiency, and all MCF requirements were addressed. This exercise covered observations from a series of underground visits to several stoping panels. A considerable time was spent in the working place, taking field notes of what was occurring. The checklists were developed to assess four areas of concern, namely the stope face, advance strike gully, central dip gully, and orepass for possible accumulation of ore. Although material census checklists were used extensively as the measuring instruments, the study relied on the experience of the researcher to identify these areas of concern from the ore flow diagram.

The fourth exercise was concerned with the tracking of ore movement from the stope face to the stope orepass. Radio frequency identification (RFID) tags were used as tracking devices (Isokangas et al., 2012 p. 874) to:

- Identify the source of ore with a high fines content;

- Indicate how long it took for the ore to be hauled to the surface

> Record any cross-tramming events over time with great accuracy.

These numbered RFID tags have a chip with an antenna encased in a hard protective plastic shell to withstand the blasting and handling process en route to the mill plant. The tag number, the stope location where the tag was placed, the name of the surveyor, time and date, as well as shaft were entered into the database. The characteristics of the ore at the particular source were recorded in the field notebook underground. The RFID tags were dropped on the broken rock at the stope face and in the advance strike gully, centre gully, and boxhole. These tags surfaced from underground with broken ore on the conveyor belt, where a tag detector recorded and passed the information to the database. A management report was extracted from the database to assess the time taken for the waste and reef to reach surface. Tagged ore sent to stockpiles can be detected at a later stage when eventually processed and then reconciled back to its source.

\section{Reliability and validity of the measuring instruments}

Since the main concerns in reliability and validity measurements were stability over time or variability of conditions, a common way to estimate reliability and convergence validity was with a measure of association and the correlation coefficient.

\section{Data analysis}

The data obtained from stopes 4 and 6 was transferred to an Excel spreadsheet and analysed using Microsoft Excel 2013. Data was analysed by means of descriptive statistics, correlations, and regression analysis.

\section{Mine-to mill-integration applications}

As a problem-solving tool, the mine-to-mill integration approach followed a particular business ore flow sheet that shows the various stages that the ore passes through before the final product is extracted. The ore flow sheet guided the sequence of analyses that the study used to indicate where to start and end measuring. The investigation begins with understanding of in-stope fragmentation for mine-to millintegration model standardization. This is followed by value stream mapping and monitoring of ore loss and dilution. Finally, the investigation closes with time tracking of ore movement from source to the mill plant.

\section{In-stope fragmentation}

An understanding of fragmentation was obtained first by visual observations of muck piles immediately following the blasting of rock in situ, and the SPLIT offline applications used to predict the size range of the actual blasted rocks (see Figure 2). Since $20 \mathrm{~mm}$ rubber balls, tennis balls, and grizzlies were used as scaling tools, an image analysis strategy was developed that estimated the size distribution of

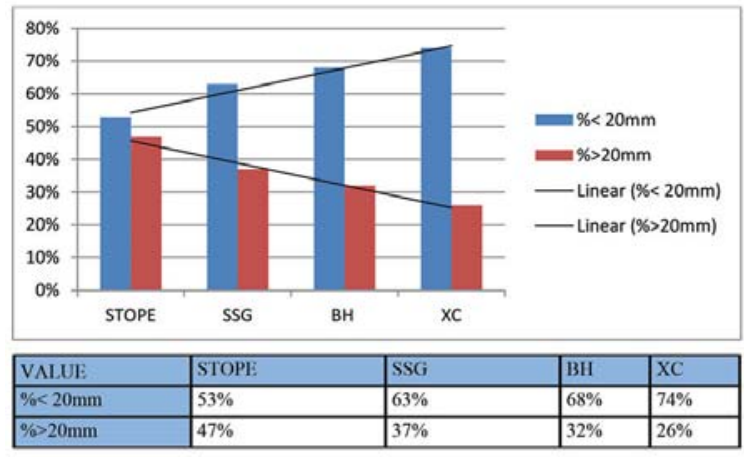

STOPE $=$ Stope face, $\mathrm{SSG}=$ Advance strike gully, $\mathrm{BH}=\mathrm{Box}$ hole (ready to be trammed), $\mathrm{XC}=$ Area around box-front in the crosscut. 


\section{Monitoring ore loss and dilution for mine-to-mill integration in deep gold mines}

the broken ore across the percentage $<20 \mathrm{~mm}$ (fines) and percentage $>20 \mathrm{~mm}$ (coarse) fragments. This strategy is summarized in Figure 2; the actual details of this process are beyond the scope of this paper.

Figure 2 indicates that the size distribution of fines was positively correlated (from $53 \%$ to $68 \%$ split of ore material) with the movement of broken ore. This means that the amount of fines increases as the broken ore moves away from the source. On the other hand, the size distribution of coarse particles is negatively correlated (from $47 \%$ to $32 \%$ split of ore material) with the movement of broken ore. This means that the amount of coarse particles decreases as the broken ore moves away from the stope face to the BH. A mean fragment size of less than $20 \mathrm{~mm}$ at sieve passing rate of $74 \%$ was observed in the crosscut. Therefore, the fines distribution of data of this bar chart is negatively skewed (to the left), while the coarse distribution is positively skewed (to the right). However, it must be noted that the mean size of the coarse distribution might be smaller than that estimated from visual inspection, since smaller fragments dominated the view after vibration and settling. Therefore, for this stope panel, $68 \%$ of the gold-bearing particles were liberated from the host rock (quartz, silicates, and pyrite) while $32 \%$ of the coarse particles were associated with or still attached to the host rock. Hence there was a need to reduce the amount of fines in the blasted material and optimize fragmentation.

\section{Investigation}

An investigation of fines distribution at the stope face indicated that the friable and carbonaceous portion of the reef, which contains the highest portion of gold, was the most shattered by blasting, broken out, and crushed into fines easily. In contrast, gangue (waste material) was mostly bigger than tennis ball size, hence the ore and waste were broken unequally. The substantial rock breakage was further exacerbated by the increase in panel length, gully length, scraper routes, and crossovers that caused the decrease in cleaning rate. The more the cleaning rate decreases, the more the coarse particles are crushed further into fines. It must be noted that gold particles are minute, associated with very fine particles, and can be as fine as $0.001 \mathrm{~mm}$. These fines become airborne and are dispersed by gaseous emissions as dust from the collection zone when the rock is blasted conventionally. These fines could also be easily waterwashed into crevices and cracks in the footwall or away to different parts of the mine during sweeping or drilling, thus increasing gold loss. The gold lost underground in this manner is commonly referred to as 'free gold'. Free gold has been a persistent problem in the mine for some time, as demonstrated by significant higher gold recoveries from the fines in the back area and mud in the crosscuts. Hence there was a need to understand the run-of-mine fragmentation.

\section{Mine-to-mill application}

The visual observations of the muck pile underground were compared with the actual fragmentation results from image analysis captured from the online digital camera through SPLIT online applications (see Figure 3).

The results in Figure 3 show a mean fragment size of $16.00 \mathrm{~mm}$ at $50 \%$ passing. In addition, the shape distribution of these fragments is consistent and negatively skewed, whereby mean $\%<$ median $\%<$ mode, indicating a finer size distribution. The greatest increase in fines content occurs between $3 \mathrm{~mm}$ and $10 \mathrm{~mm}$ as well as between $50 \mathrm{~mm}$ and $100 \mathrm{~mm}$, as shown by the steepness of the curve between these class boundaries. Hence, approximately $92.17 \%$ of the fragments will not require crushing as they will pass smoothly through the primary crusher to the secondary crusher screen. This means there a greater percentage of finer fragments was fed to the mills on 4 of July. It is clear from Figures 2 and 3 that the estimates of size distribution of fragments in both cases are very close to each other.

The choice of using Anfex explosives in development ends and Powergel (cartridge) explosives in stope panels was mainly based on rock breakage requirements. Subsequently, drilling patterns and overcharging remain the cause of the increased fragmentation that leads to losses of gold in the fine fractions produced. The production of excessive of fine materials and dust is not desirable in gold mines in that it:

> Poses a health hazard to the workers underground (a cause of silicosis and tuberculosis)

> Is not easy to collect in subsequent scraping, loading, and hauling operations, leading to losses of gold.

\section{Monitoring of ore dilution}

The blasted broken ore in the stopes is a mixture of waste rock and gold-bearing rock (reef). No matter how careful the personnel are to mine only reef, there will always be waste rock diluting the grade of ore going to the mill for processing. A gap analysis report of eight stope panels (Table I) was prepared to assist mine management understand why the ore tonnage and gold content were not being reflected further along the production stream.
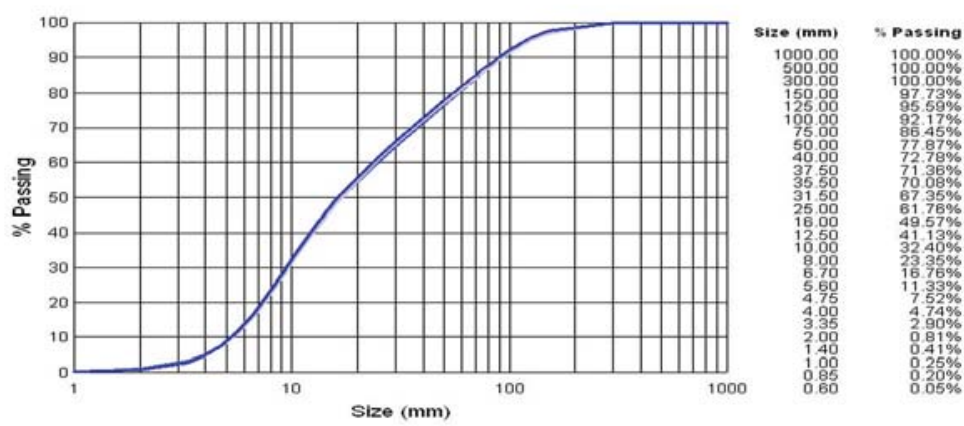

Figure 3-Cumulative size distribution generated by SPLIT online desktop program as at 4 of July 2013 


\section{Monitoring ore loss and dilution for mine-to-mill integration in deep gold mines}

Table I shows that all SCF score values for the eight stope panels are above $60 \%$ and that the values of chip and grab samples are practically significant, related to each other, and confirm the convergence validity of the techniques. However, since grab samples were collected from the fines, grab sampling tended to overstate the grade of the diluted waste block by $14.29 \%$ to $160.5 \%$ and understate the grade of the high-grade block by $8.54 \%$ to $81.34 \%$. Even though the assay values of these stope panels were variable, most of the gold particles were located in the fines and this is a cause of concern for the mine-to-mill reconciliation and metal accounting system. The grade variability of the mine-to-mill integration model was explained by dilution, which can be up to $100 \%$ where off-reef is mined.

\section{Investigation}

On investigation, it was found that the gold mineralization is associated with weak host rock and geological features such as faults, sills, and dykes. Deposits within weak host rocks with indistinct contacts are usually associated with caving of sidewalls and the hangingwall, resulting in high dilution. It was also observed that where an ideal stoping width was maintained, drilled holes were drilled into the narrow reef.
During blasting the gold-bearing material was scattered far and wide in the stope panel, leaving behind large quantity of waste rock. Evidence of this was in the form of the high gold content of the fines that covered mat packs and contaminated the swept area. In addition to the large quantity of waste rock broken from the stope face, it is important to consider also the waste from footwall scraping during cleaning, barring of brows, and falls of ground, faults, intrusions, and footwall lifting in gullies. These waste materials contaminate the ore in the downstream process. However, an overall analysis of gold concentration at the face, and in the gullies and orepasses (hoppers to the station) (Table II) indicated that the assay values had a significant positive correlation, with a coefficient of 0.9291 (Table III).

\section{Mine-to-mill application}

Although it is impossible or impractical to eliminate dilution completely, it can be measured (Figure 4) and controlled (Figure 5) with some degree of precision. What is required is for the orebody to be properly delineated and the extracted volumes to be effectively measured. It is a common practice to make general assumptions of $5 \%$ dilution for massive deposits and $10 \%$ for tabular deposits, instead of measuring

\section{Table I}

Grade gap analysis report

\begin{tabular}{|c|c|c|c|c|c|c|c|c|c|c|}
\hline & Panel & Stope & ASG & CDG & Av. (grab) & Av. (chip) & Boxholes & X-CUT & SCF & Grade gap \\
\hline 1 & $\begin{array}{c}\text { Stope } 4 \\
15.0 \mathrm{~m}(\mathrm{M} / \mathrm{P})\end{array}$ & $\begin{array}{c}7.400 \\
10.655\end{array}$ & $\begin{array}{l}10.119 \\
\text { Water }\end{array}$ & 9.470 & 9.411 & 8.033 & 11.478 & 8.673 & $\begin{array}{l}117.30 \% \\
\text { Overstate }\end{array}$ & $+14.29 \%$ \\
\hline 2 & $\begin{array}{c}\text { Stope } 5 \\
11.5 \mathrm{~m}(\mathrm{M} / \mathrm{P})\end{array}$ & $\begin{array}{l}4.018 \\
4.755\end{array}$ & 4.566 & 4.303 & 5.233 & 3.701 & 6.561 & $82.22 \%$ & $\begin{array}{c}-8.54 \% \\
\text { Understate }\end{array}$ & \\
\hline 3 & $\begin{array}{c}\text { Stope } 6 \\
14.0 \mathrm{~m}(\mathrm{~S} / \mathrm{A})\end{array}$ & $\begin{array}{l}5.434 \\
6.342 \\
\end{array}$ & 3.725 & 3.552 & 4.763 & 6.933 & 3.107 & 3.194 & $\begin{array}{c}68.70 \% \\
\text { Understate }\end{array}$ & $-81.34 \%$ \\
\hline 4 & $\begin{array}{c}\text { Stope } 7 \\
14.5 \mathrm{~m}(\mathrm{~S} / \mathrm{A})\end{array}$ & $\begin{array}{l}13.207 \\
18.604\end{array}$ & $\begin{array}{l}10.538 \\
\text { Water }\end{array}$ & 7.163 & 12.410 & 16.167 & 9.426 & 7.245 & $\begin{array}{c}76.76 \% \\
\text { Understate }\end{array}$ & $-51.87 \%$ \\
\hline 5 & $\begin{array}{c}\text { Stope } 8 \\
14.0 \mathrm{~m}(\mathrm{M} / \mathrm{P})\end{array}$ & $\begin{array}{l}9.191 \\
8.343 \\
\end{array}$ & $\begin{array}{l}5.697 \\
\text { Water }\end{array}$ & $\begin{array}{c}7.289 \\
\text { Same CG }\end{array}$ & 7.630 & 9.100 & 6.902 & 7.781 & $\begin{array}{c}83.84 \% \\
\text { Understate }\end{array}$ & $-14.49 \%$ \\
\hline 6 & $\begin{array}{c}\text { Stope } 9 \\
15.0 \mathrm{~m}(\mathrm{~S} / \mathrm{A})\end{array}$ & $\begin{array}{l}3.695 \\
2.392\end{array}$ & 3.475 & 3.175 & 3.184 & 5.000 & 5.058 & 7.059 & $\begin{array}{c}63.68 \% \\
\text { Overstate }\end{array}$ & $+11.60 \%$ \\
\hline 7 & $\begin{array}{c}\text { Stope } 10 \\
13.0 \mathrm{~m}(\mathrm{M} / \mathrm{P})\end{array}$ & $\begin{array}{l}3.944 \\
0.584\end{array}$ & 2.473 & 1.953 & 2.239 & 0.700 & 1.556 & 2.400 & $\begin{array}{l}319.86 \% \\
\text { Overstate }\end{array}$ & $+122.3 \%$ \\
\hline 8 & $\begin{array}{c}\text { Stope } 11 \\
18.0 \mathrm{~m}(\mathrm{~S} / \mathrm{A})\end{array}$ & $\begin{array}{l}4.467 \\
3.191\end{array}$ & 2.400 & 4.800 & 3.715 & 0.600 & 1.563 & 2.791 & $\begin{array}{l}619.17 \% \\
\text { Overstate }\end{array}$ & $\begin{array}{l}+160.5 \% \\
\text { Overstate }\end{array}$ \\
\hline
\end{tabular}

$\mathrm{M} / \mathrm{P}=$ Mat packs S/A = Swept area

Table II

Tonnage inventory of underground accumulation of broken ore

\begin{tabular}{|c|c|c|c|c|c|c|c|c|c|c|c|c|c|}
\hline & \multicolumn{4}{|c|}{ Stope face (RD = 1.62) } & \multicolumn{3}{|c|}{ Advance strike gully $(\mathrm{W}=2.0 \mathrm{~m})$} & \multicolumn{3}{|c|}{ Central dip gully (W = $2.0 \mathrm{~m})$} & \multicolumn{3}{|c|}{ Boxhole $(\mathrm{W}=1.4 \mathrm{~m})$} \\
\hline & $\mathbf{L}$ & B & $\mathrm{H}$ & Tons & L & $\mathrm{H}$ & Tons & $\mathbf{L}$ & $\mathrm{H}$ & Tons & L & $\mathrm{H}$ & Tons \\
\hline Stope 4 & 41 & 24 & 0.6 & 956 & 126 & 1.0 & 408 & 35 & 0.9 & 102 & 33 & 2.0 & 150 \\
\hline Stope 5 & 28 & 10 & 0.3 & 136 & 98 & 1.0 & 318 & 5 & 1.1 & 18 & 27 & 2.0 & 122 \\
\hline Stope 6 & 24 & 10 & 0.5 & 194 & 47 & 0.3 & 46 & 30 & 0.7 & 68 & 21 & 2.0 & 95 \\
\hline Stope 7 & 25 & 10 & 0.3 & 122 & 35 & 0.4 & 45 & 5 & 0.8 & 10 & 17 & 2.0 & 77 \\
\hline Total & & & & 1408 & & & 817 & & & 198 & & & 227 \\
\hline
\end{tabular}




\section{Monitoring ore loss and dilution for mine-to-mill integration in deep gold mines}

it (Ebrahimi, 2013, p. 1). This assumption differs from mine to mine. The comparison of daily head grade and daily blasted grade is depicted in Figure 4.

From a comparison of the total mine daily blasted grade and the plant head grade (Figure 4), it is obvious that grade variation does exist, although the overall pattern is quite stable with few outliers such as $10.25 \mathrm{~g} / \mathrm{t}$ (13 June), 10.45 $\mathrm{g} / \mathrm{t}$ (21 June), and $9.36 \mathrm{~g} / \mathrm{t}$ (3 July). A monthly grade variation of approximately $52.59 \%$ due to dilution is shown, and can be used to estimate the dilution rate for the forthcoming months, provided that corrective measures are implemented. This means that the daily blasted grade would always be greater than the daily head grade; therefore the MCF would always be less than $100 \%$. An investigation regarding the discrepancy between the estimation of daily head grade and daily blasted grade is beyond the scope of this study. The answer to this might lie in the fact that the estimates of shaft head grade include the grades of development ore (waste and reef), sweepings from old areas, and other sources, not all of which were sampled (Bartlett, Korff, and Minnitt, 2014, p. 109). The grade of broken ore hoisted from underground (daily head grade) is not equivalent to the grade measured on the faces (daily blasted grade)
Figure 5 demonstrates how dilution can be controlled for a properly delineated orebody.

Figure 5 indicates that in December, an average reef channel width of $17 \mathrm{~cm}$ was mined out with $130 \mathrm{~cm}$ of external waste, resulting into a dilution of $88.4 \%$. The annual dilution of this unit ranges from $68.6 \%$ to $89.6 \%$, the peak being in September. Over a twelve-month period, the reef was steadily becoming thinner. Subsequently, as mining progresses, more waste would be included in the muck piles and the mill feed grade would decrease. A grade of $24.6 \%$ gold was reported in January, decreasing to $13.0 \%$ in December. In this way dilution can be measured and can be controlled by reducing external waste. The financial impact of dilution on the mining operation is due to the extra costs involved in mining and processing of the waste $(130 \mathrm{~cm})$ that is treated as ore.

An ore with a dilution rate of $88.4 \%$ should not be sent to the mill for processing, but action must be taken to separate waste from the ore either underground or on surface. If this is not possible, then this material must be treated as waste and dumped. For instance, if the processing cost was R200 per ton, a dilution rate of $88 \%$ would mean that R176 is spent on processing waste as ore in the mill. It is clear that the mill processing costs would increase directly by an

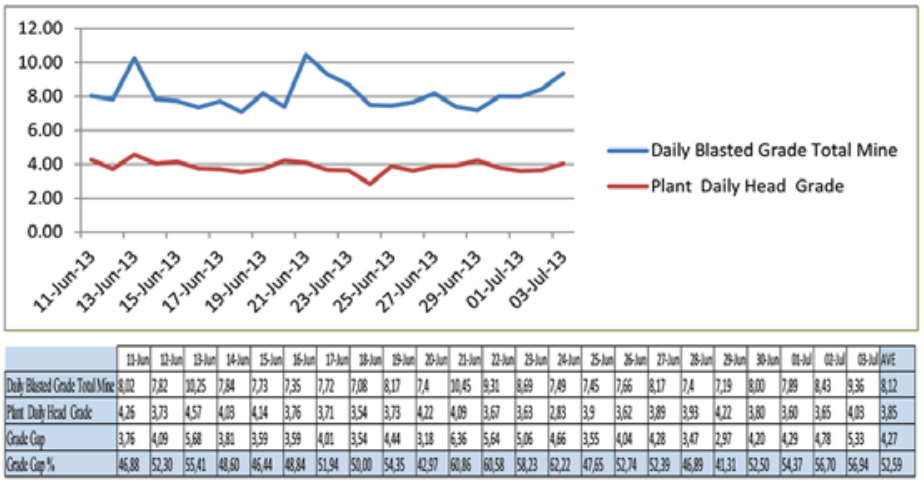

Figure 4-Dilution as shown by daily blast grade and daily head grade

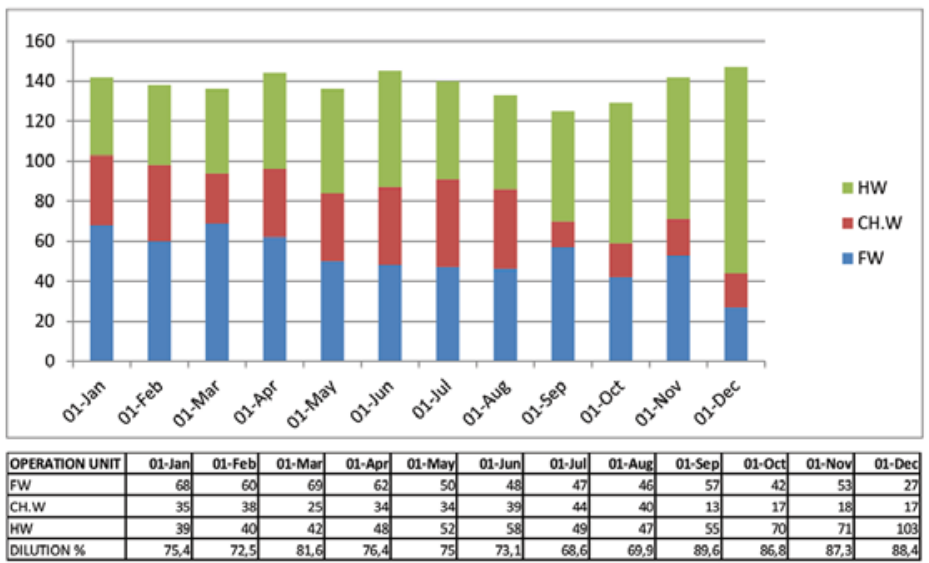

Figure 5-Analysis of external dilution for a properly delineated orebody 


\section{Monitoring ore loss and dilution for mine-to-mill integration in deep gold mines}

amount equal to the dilution factor. Reduction of external waste would result in less tonnage at a higher grade being sent to the plant. This dilution of ore with waste would mean low-grade ore will be processed instead of high grade ore. This would impact negatively on the MCF.

\section{Monitoring ore loss}

As discussed previously, gold losses occur when gold-bearing material is misclassified as waste and sent to the waste dump, reef is left behind in the footwall and hangingwall, excessive waste is mined, blocks of reef are left behind as permanent support pillars, and ore locked up underground is not removed in time to form part of the current metal accounting system. The latter factor is the focus of this study. The real gold loss must be found underground, if the loss occurs during mining operations, but if it cannot be found underground it can only be ascribed as apparent gold loss. Table II is a hypothetical, but realistic, example to illustrate how much of the gold-bearing material was lost in the extraction process.

Table II indicates that there was accumulation of broken ore at the faces in stopes 4 and 5 , gullies, and orepass during the movement of ore. The movement of ore in the stope is the result of blasting, face cleaning, gully scraping, and loading from the orepass. These are the potential areas of tonnage accumulation. The tonnage accumulations consist of current broken ore that is called for but was not removed in time to form part of the current metal accounting system. The inability to locate the exact points of accumulation of ore underground and quantify the volume and value of goldbearing material remaining underground over time has led to a declining MCF.

\section{Investigation}

On investigation, it was found that the accumulation of ore underground was due to the long face length and scraping distance in the gully. As the gully length, scraper routes, and crossovers increase, the more the cleaning rate decreases and coarse particles are crushed further into fines. Work in general, in particular scraper cleaning, becomes difficult, leading to the accumulation of ore in the back area, sidings (north and south) and gullies. This indicates that sweeping of back area was not done on daily basis as part of the mining cycle. If panels are not timeously swept, falls of ground may occur and cover up vast areas of backlog sweepings that will never be removed due to safety issues. Excessive accumulation of material in the gully reduces the gully depth if not pulled to the footwall regularly. A shallow gully has insufficient storage capacity when an orepass is filled up due to tramming delays, resulting into spillage along the shoulders and adjacent swept panel, amounting to gold loss. This means that these gullies would not be scraper-cleaned to the footwall regularly. Two of the reasons that were noted for not scraping the gully to the footwall regularly were offline development of the gully and the use of $37 \mathrm{~kW}$ winch with one scoop to clean the scraping distance of more than $60 \mathrm{~m}$. The offline gullies observed created major cleaning bottlenecks associated with damaged gully shoulders, large gully span, accumulation of broken ore, water in the gully, and spillage along the shoulders of the gully.

\section{Mine-to-mill application}

Figure 6 indicates how accurate the estimate turned out to be compared to the quantity of metal recovered plus residue.

Figure 6 indicates that the estimated hoisted gold and gold recovered at the plant show parallel trends over time; the increments of the two variables are the same and there is an ore loss or overestimation of about $17 \%$ (in kilograms) between the underground source to the surface plant. This means that more tonnage with low grade was sent to the mill for processing, resulting into low overall recovery. A MCF of $83 \%$ seems justified to estimate the amount of gold to be recovered in forthcoming months, provided that all other variables stay the same.

\section{Data analysis}

In an attempt to ascertain the impact of ore movement on the head grade at the mine, correlation and regression analysis were applied.

\section{Correlation coefficient analysis}

The current study was correlational in nature as it was designed to assist understanding of how gold was lost between the source (stope face) and the shaft main tips. The correlation coefficient is one of the techniques used to estimate reliability of this study by measuring the correlation

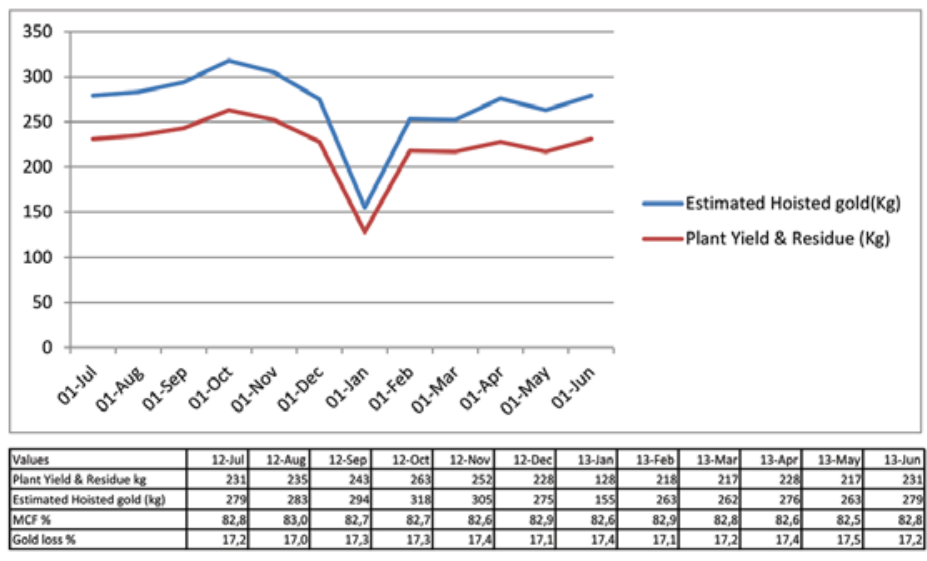

Figure 6-Discrepancy between hoisted tonnage and plant tonnage 


\section{Monitoring ore loss and dilution for mine-to-mill integration in deep gold mines}

between the distance from the source to the shaft and the gold content. The discussion above showed that the size distribution of fines was positively correlated and the coarse negatively correlated, but this is only a qualitative indication. The correlation coefficient provides a quantitative measure of the relationship. For example, the correlation coefficients for stopes 4 and 6 are presented in Table III and Figures 7 and 8.

There is a positive correlation coefficient of 0.9130 between distance and grade as the broken ore moves from stope to the shaft main orepass, and a negative correlation coefficient of -0.97079 in the case of stope 6 . A high correlation coefficient indicates a convergent validity. A positive relationship shows that as the distance from the stope face to the orepass increases, so does the fines content (gold content) of the broken ore. Since both correlation coefficients are close to unity, there is a strong correlation between the gold content and distance between the source and main shaft orepass.

\section{Regression analysis}

Regression analysis was performed to determine the extent to which the distance to the main shaft orepass would explain the variance in grams per ton (value) of the ore broken from the stope face. The discussion deals with the application of regression to firstly estimate or predict the quantitative effect of the distance upon the values, and secondly to determine the statistical significance of the estimated relationships. The summary of the Excel regression output is presented in Table IV (for the case where gold is evenly distributed over the width of the reef) and Table $\mathrm{V}$ (gold is concentrated near the footwall contact of the reef).

In Table $\mathrm{V}$, the $\mathrm{R}^{2}$ value of 0.833 indicates that most of the data has some linear relationship, with some degree of scatter; a very good fit as $\mathrm{R}^{2}$ is close to unity. This means $83 \%$ of the variation in the grade is explained by the length of the gully. However, the relationship between these two variables is statistically insignificant at a significance level $\alpha$ $=0.05$ as $p>0.05$, with $\mathrm{P}$-value $=0.0870$ despite the correlation coefficient of 0.913 . This means that the distance of movement of ore from a thick reef (where gold is evenly distributed over the width) does not have an adverse effect on the grade gap. In other words, for each unit increase in length at $7.385 \mathrm{Y}$-intercept, the grade increases by 0.019 units.

In Table $\mathrm{V}, \mathrm{R}^{2}$ the value of 0.942 indicates that most of the data has some linear relationship, while some is scattered, a very good fit as $\mathrm{R}^{2}$ is closer to unity. This means that $94 \%$ of the grade variation is explained by the length of the gully. The table also show that the relationship between the length and grade is statistically significant $(p<0.05$, with quantitative effect of 0.0292) despite an inverse relationship of -0.97079 . This means that the distance of movement of ore from a thin reef (where gold is concentrated near the footwall contact) does have an adverse effect on the grade gap. In other words, for each unit increase in length at 4.708 Y-intercept, the grade decreases by 0.016 units. It can therefore be deduced that the grade gap between the source and the plant is very variable due to the uncertainty of many grade-controlling parameters, in particular the dynamics of ore movement.

Having tested the relationship between the transport distance and grade, it is now possible to determine the time lag between the measuring and milling month and track the source of material being fed into the crushing and grinding circuits.

\section{Stope 4: Ore movement}

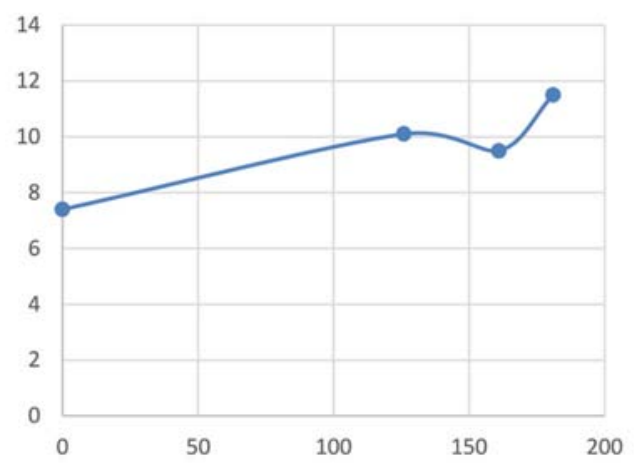

Figure 7-Positive correlation

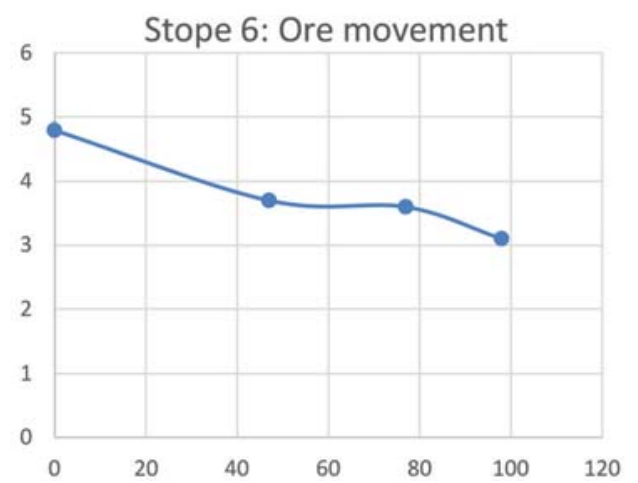

Figure 8-Negative correlation

Table III

Determining correlation coefficient of Stope 4 and 6

\begin{tabular}{|l|c|c|c|}
\hline & \multicolumn{2}{|c|}{ Stope 4 } & \multicolumn{2}{c|}{ Stope 6 } \\
\cline { 2 - 4 } & Distance from face (cumulative) & Grams per ton & Distance from face (cumulative) \\
\hline Stope face & 0 & 7.4 & 0 \\
Adv. strike gully & 126 & 10.1 & 47 \\
Central dip gully & 161 & 9.5 & 77 \\
Box hole & 181 & 11.5 & 3,7 \\
\hline
\end{tabular}




\section{Monitoring ore loss and dilution for mine-to-mill integration in deep gold mines}

\begin{tabular}{|c|c|c|c|c|c|c|c|c|}
\hline \multicolumn{9}{|c|}{$\begin{array}{l}\text { Table IV } \\
\text { Regression analysis: Influe }\end{array}$} \\
\hline \multicolumn{9}{|c|}{ Regression statistics } \\
\hline \multicolumn{2}{|c|}{$\begin{array}{l}\text { Multiple R } \\
\text { R Square } \\
\text { Adjusted R Square } \\
\text { Standard Error } \\
\text { Observations }\end{array}$} & $\begin{array}{c}0,912961608 \\
0,833498897 \\
0,750248346 \\
0,851413047 \\
4\end{array}$ & & & & & & \\
\hline \multicolumn{9}{|l|}{ ANOVA } \\
\hline & df & SS & MS & $\mathbf{F}$ & Significance $F$ & & & \\
\hline \multirow[t]{2}{*}{$\begin{array}{l}\text { Regression } \\
\text { Residual } \\
\text { Total }\end{array}$} & $\begin{array}{l}1 \\
2 \\
3\end{array}$ & $\begin{array}{c}7,257691647 \\
1,449808353 \\
8,7075\end{array}$ & $\begin{array}{l}7,257692 \\
0,724904\end{array}$ & 10,01193245 & 0,087038392 & & & \\
\hline & Coefficients & Standard Error & t Stat & P-value & Lower 95\% & Upper 95\% & Lower 95,0 & Upper 95,0 \\
\hline $\begin{array}{l}\text { Intercept } \\
\text { Value }\end{array}$ & $\begin{array}{c}-302,0453632 \\
43,53718059\end{array}$ & $\begin{array}{c}133,9817346 \\
13,7594586\end{array}$ & $\begin{array}{l}-2,25438 \\
3,164164\end{array}$ & $\begin{array}{l}0,152886 \\
0,087038\end{array}$ & $\begin{array}{c}-878,522 \\
-15,665\end{array}$ & $\begin{array}{l}274,4315 \\
102,7394\end{array}$ & $\begin{array}{c}-878,522 \\
-15,665\end{array}$ & $\begin{array}{l}274,4315 \\
102,7394\end{array}$ \\
\hline
\end{tabular}

Table $V$

Regression analysis: Influence of distance on grade value of Stope 6

\begin{tabular}{|c|c|c|c|c|c|c|c|c|}
\hline \multicolumn{9}{|c|}{ Regression statistics } \\
\hline \multicolumn{2}{|c|}{$\begin{array}{l}\text { Multiple R } \\
\text { R Square } \\
\text { Adjusted R Square } \\
\text { Standard Error } \\
\text { Observations }\end{array}$} & $\begin{array}{c}0,970786114 \\
0,94242568 \\
0,91363852 \\
0,210552194 \\
4\end{array}$ & & & & & & \\
\hline \multicolumn{9}{|l|}{ ANOVA } \\
\hline & df & SS & MS & $\mathbf{F}$ & Significance $\mathbf{F}$ & & & \\
\hline \multirow[t]{2}{*}{$\begin{array}{l}\text { Regression } \\
\text { Residual } \\
\text { Total }\end{array}$} & $\begin{array}{l}1 \\
2 \\
3\end{array}$ & $\begin{array}{c}1,451336 \\
0,088664 \\
1.54\end{array}$ & $\begin{array}{l}1,451336 \\
0.044332\end{array}$ & 32,73771 & 0,029213886 & & & \\
\hline & Coefficients & Standard Error & t Stat & P-value & Lower 95\% & Upper 95\% & Lower 95,0 & Upper 95,0 \\
\hline $\begin{array}{l}\text { Intercept } \\
\text { Value }\end{array}$ & $\begin{array}{l}274,3701299 \\
-57,5974026\end{array}$ & $\begin{array}{l}38,75931612 \\
10,06650595\end{array}$ & $\begin{array}{l}7,078818 \\
-5,72169\end{array}$ & $\begin{array}{l}0,019378 \\
0,029214\end{array}$ & $\begin{array}{c}107,6022525 \\
-100,9100819\end{array}$ & $\begin{array}{c}441,138 \\
-14,2847\end{array}$ & $\begin{array}{c}107,6023 \\
-100,91\end{array}$ & $\begin{array}{c}441,138 \\
-14,2847\end{array}$ \\
\hline
\end{tabular}

\section{Ore tracking analysis}

The real gold loss must be traceable if lost during mining operations, but if it cannot be located underground it can only be ascribed as apparent gold loss. It is of vital importance that movement of ore from the source to the mill is understood to reduce ore loss and dilution in order to improve the MCF. Table VI depicts the time lag between underground production and milling.

Table VI indicates the time the RFID tags were planted in the muck piles at the source and the detection time at the conveyor belt on surface. The fluctuations in the monthly mined value and the time lag of approximately 20 days between production and milling also result in variations in the MCF. The time delays may therefore be extremely variable, making it difficult to estimate the mine process inventory and develop a metal accounting system with a fair degree of confidence. Only one reef tag (A5756) was read at $22 \mathrm{~h} 56$ as going to the waste dump. This means gold-bearing material is still classified as waste and sent to the waste dump, a potential loss of gold. The highlighted tags were those that correspond to top ten high-grade panels of their respective shafts and their low recovery rates indicate that high-grade ore does not reach surface timeously, if at all. The slow arrival of high-grade ore causes a low MCF and complicates mine-to-mill reconciliation. The financial impact of ore loss on the mining operation equals the revenue that is forfeited when ore is not delivered from the mine to the plant. With this information, corrective measures can be taken quickly. Ore tracking reports are sent on a weekly basis to the manager, listing the tags that have not yet passed the reader. If the tracking system is effective, ore loss and dilution can be estimated by correlating the time the tag was dropped at the stope face and the time it was detected on the conveyor belt. For tags A5711 and A5712 movements of $181 \mathrm{~m}$ and time lags of 15 days were recorded, and these have significant implications for dilution and ore loss. The inability to locate the exact points of ore accumulation underground and to quantify the volume and value of gold-bearing material remaining underground over time has led to a declining MCF. 


\section{Monitoring ore loss and dilution for mine-to-mill integration in deep gold mines}

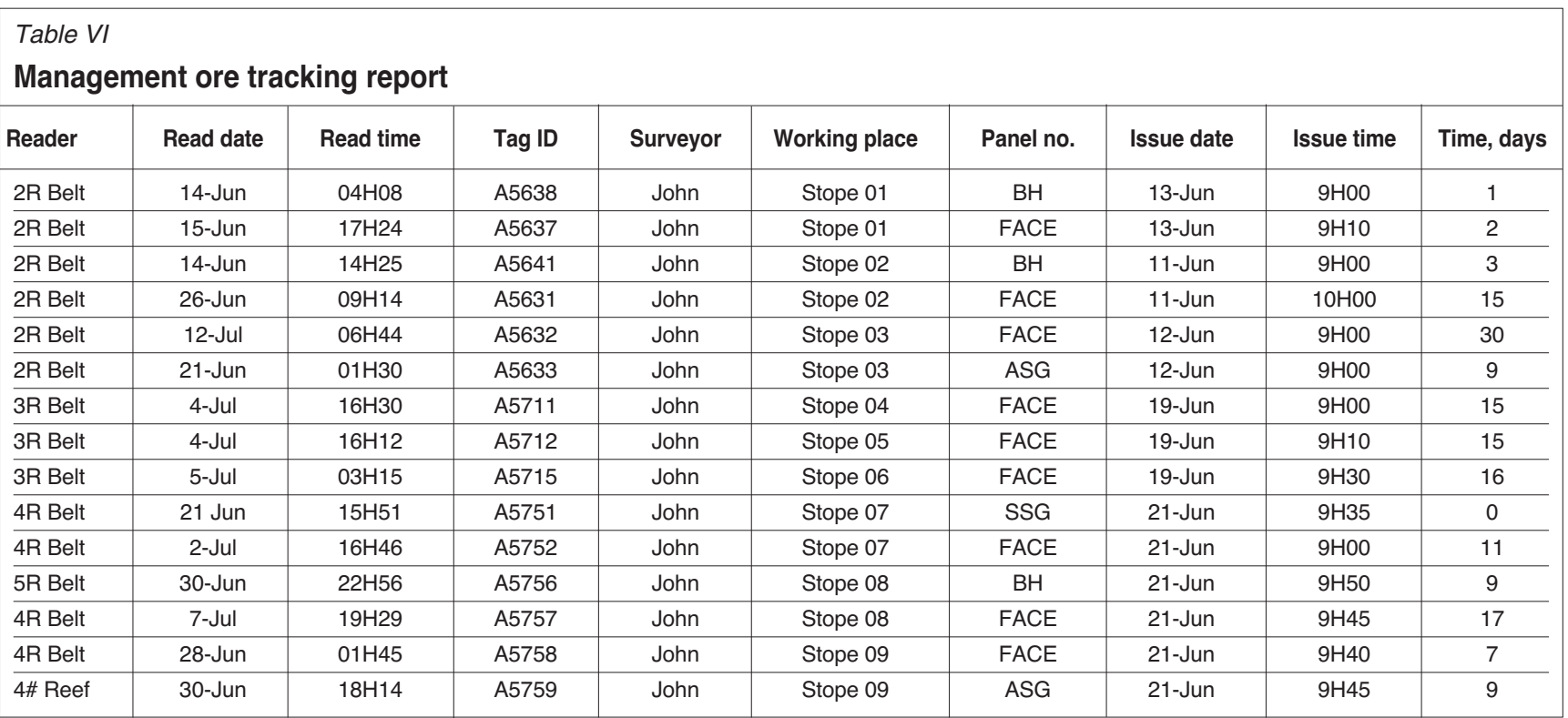

\section{Conclusions and recommendations}

This study was aimed at increasing mine output and profit margin by controlling fragment size distribution, managing grade variability, and ensuring that broken ore reaches the mill plant timeously. Movement of rock, ore loss, and dilution are the consequence of blasting the rock in situ. Hence, efficiency ore management mine necessitates the need to measure accurately, firstly the fragment size distribution, then ore loss and dilution, and thereafter track ore movement after blasting from the stope face to the concentration plant. The findings of the study have shown that it is difficult to quantify the total ore loss due to the time lag between breaking of the rock and processing of the ore to the final product when estimating the mine process inventory. The inability to minimize ore loss can thus impact negatively on mine output through the loss of revenue. However, it is possible to estimate the total dilution with some degree of precision by analysing the daily blast grade and daily head grade. Ore dilution can also impact negatively on the mine profit margin as a result of the extra costs involved in mining and processing of the waste that is treated as ore. The feed to the concentrator should preferably contain a sufficient amount of high-grade gold ore and be as homogeneous as possible for stable plant operation. However, ore below the pay limit adds variation to the mill grade as increased mill throughput will be required to make up for the loss of gold, and that impacts on the recovery in the plant. It is against these perspectives and findings of this study that the MCF should be seen as a method that identify the real problems underground and when these are addressed, the profitability of the mine will increase.

A satisfactory mine output and margins can be achieved by the correct application of the mine-to-mill approach discussed above. It is therefore recommended that the mine accept that ore losses and dilution will always occur during blasting and moving of broken ore, and this loss must be kept at a minimum. It is worth mentioning that a MCF investigation is likely to be successful when initiated and supported by management.

\section{Limitations}

> The focus in this research was on real gold loss between the source and the stope orepass. It would have been useful and interesting to analyse the relationship between the apparent gold loss and the mine call factor

> The empirical study was carried out for academic purposes and therefore the time allocated was limited, hence a cross-sectional survey was performed. The true results could have been obtained through a longitudinal study and testing of reversal causal effects

> Three short case studies were undertaken to understand the impact of ore loss and dilution on the MCF. This situation varies widely from mine to mine, depending upon the problems posed and managerial policy. The ability to extend the results of the study to the wider South African mining industry is therefore limited

> RFID tags were place at the working place in the reef horizon only. Information regarding the classification of waste as reef could have been obtained to minimize dilution of broken ore sent to the mill

> Due to the limited availability of resources and time allocated for this project, it was not possible to visit all stope working places.

The following extract seems appropriate to conclude this paper with:

'...for a higher grade deposit, the cost of ore loss and misclassification has a greater impact than the cost of dilution, hence it may be preferable to accept more dilution to minimise the cost of ore loss and misclassification' and '... for a lower grade deposit, the cost of dilution has a greater impact than the cost of ore loss..., hence it may be preferable to accept more ore loss and misclassification to minimise the cost of dilution...' (Singh and Sinha, 2013, p. 263).

\section{Acknowledgements}

My thanks to Chris Opperman, Ndubuzo Shange, and Lazarus Phutheho for their contributions to this study. 


\section{Monitoring ore loss and dilution for mine-to-mill integration in deep gold mines}

\section{References}

ANDERSEN, D.C. 1999. Criteria influencing the mine call factor of a gold mine. Selected topics in mining engineering. Faculty of Mining Engineering, University of the Witwatersrand, Johannesburg.

BAMBER, A.S. 2008. Integrated mining, pre-concentration and waste disposal systems for the increased sustainability of hard rock metal mining. Doctoral thesis, University of British Columbia, Vancouver.

BARTLETT, H.E., KoRfF, L., and MinNitT, R.C.A. 2014. The allocation of gold production from multiple shafts feeding a common treatment plant using run-of-mine sampling of ore deliveries. Journal of the Southern African Institute of Mining and Metallurgy, vol. 114. pp. 109-120.

CAnDY, G. 2014. New tech to help gold miners tackle tough veins. Mineweb.

CHAPMAN, R. and Bindoff, M. 2010. The placer gold mining game. School of Earth and Environment, University of Leeds:

Chieregati, A.C. and Pitard, F.F. 2009. The challenge of sampling gold. Proceedings of the Fourth World Conference on Sampling and Blending. Southern African Institute of Mining and Metallurgy, Johannesburg.

Сно, S.H. and Kаnеко, K. 2004. Rock fragmentation control in blasting. Mining and Materials Processing Institute of Japan, vol, 45, no.5. pp. 1722-1730.

Dance, A., Valery, W., Jankovic, A., La Rosa, D., and Esen, S. 2006. Higher productivity through cooperative effort: A method of revealing and correcting hidden operating inefficiencies. Proceedings of SAG 2006, Vancouver, 23-27 September 2006. CIM, Montreal. pp IV-375.

De Jager, C.P. 2005. Risk management in mining and minerals economics as well as minerals resources management. Master's dissertation. University of the Witwatersrand, Johannesburg.

Dominy, S.C. 2010. Grab sampling for underground gold mine grade control. Journal of the Southern African Institute of Mining and Metallurgy, vol. 110. pp. 277-287.

EBRAнimi, A. 2013. The importance of dilution factor for open pit mining practices. [A modified version of: An attempt to standardize the estimation of dilution factor for open pit mining projects]. Proceedings of the World Mining Congress, Montreal.

Engmann, E., Ako, S., Bisiaux, B., Rogers, W., and Kanchibotla, S. 2013. Measurement and modelling of blast movement to reduce ore losses and dilution at Ahafo Gold Mine in Ghana. Ghana Mining Journal, vol. 14. pp. 27-36.

IsoKAngas, E., Sonmez, B., Wortley, M., and VAlery, W. 2012. Using Smarttag to track ore in process integration and optimization projects: Some case studies in a variety of applications. Journal of the Southern African Institute of Mining and Metallurgy, vol. 112. pp. 871-892.

GiLLOT, P.L. 2004. Pit-to-plant optimisation at Morila Gold Mine. Morila Gold Mine, Bamako, Ghana.

Grundstrom, C., Kanchibotla, S.S., Jankovich, A., and Thornton, D. 2001. Blast fragmentation for maximising the SAG mill throughput at Porgera Gold Mine. Julius Kruttschnitt Mineral Research Centre, Brisbane.
Kanchibotla, S.S., Valery, W., and Morrel, S. 1999. Modelling fines in blast fragmentation and its impact on crushing and grinding. Proceedings of Explo'99. Australasian Institute of Mining and Metallurgy, Melbourne. pp. 137-144.

La Rosa, D. and Thornton, D. 2011. Blast movement modelling and measurement. Proceedings of the 35th APCOM Symposium, Wollongong, New South Wales, 24-30 September.

Macfarlane, A. 2011. Reconciliation along the base metal value chain Proceedings of the 6th Southern African Base Metals Conference. Southern African Institute of Mining and Metallurgy, Johannesburg. pp. 345-356.

MinNiTT, R.C.A. 2007. Sampling: the impact on costs and decision making. Journal of the Southern African Institute of Mining and Metallurgy, vol. 107. pp. 451-462.

ONEDERRA, I. 2004. Breakage and fragmentation modelling for underground production blasting applications. Julius Kruttschnitt Mineral Research Centre, University of Queensland, Australia.

Rajpot, M.A. 2009. The effect of fragmentation specification on blasting cost. Master's thesis, Queen's University, Kingston, Ontario, Canada.

Rogers, W., Kanchibotla, S.S., Tordoir, A., Ako, S., Engmann, E., and Bisiaux, B. 2012. Solutions to reduce blast-induced ore loss and dilution at Ahafo Gold Mine in Ghana. Proceedings of the 2012 SME Annual Meeting and Exhibit 2012, Seattle, Washington. Preprints, pp. 19-22.

RUPPRECHT, S.M. 2003. Best practice for personnel, material and rock transportation in ultra-deep level gold mines. Doctoral thesis, University of Natal, Durban.

Siddioui, F.I., Ali Shah, S.M., and Behan, M.Y. 2009. Measurement of size distribution of blasted rock using digital image processing. JKU Engineering Science, vol. 20. no.2. pp. 81-93

Singh, P.K. and Sinha, A. 2013. Rock Fragmentation by Blasting. Taylor \& Francis, London.

SPANGENBERG, I.C. 2012. The status of sampling practice in the gold mining industry in Africa: Working towards an international standard for gold mining sample practices. Master's dissertaton, University of the Witwatersrand, Johannesburg.

Thornton, D.M., Kanchibotla, S., and Brunton, I.D. 2002. Modelling the impact of rock mass and blast design variation on blast fragmentation. Fragblast, vol. 62. pp.169-183.

WANG, W., HuANG, S., Wu, X., and MA, O. 2011. Calculation and management for mining loss and dilution under 3D visualization technical condition. Journal of Software Engineering and Applications, vol. 4. pp. 329-334.

YiLMAZ, E. 2011. Advances in reducing large volumes of environmentally harmful mine waste rocks and tailings. Department of Applied Sciences, University of Québec at Abitibi-Temiscamingue (UQAT).

ZAGREBA, S.V. 2003. FRAGM: A blasting fragmentation model of rocks, Master's thesis, Department of Mining Engineering. West Virginia University. 